\title{
ASYMPTOMATIC HYPONATREMIA IN PULMONARY TUBERCULOSIS ${ }^{1}$
}

\author{
By E. A. H. SIMS, ${ }^{2}$ LOUIS G. WELT, ${ }^{3}$ JACK ORLOFF, ${ }^{4}$ AND JAMES W. NEEDHAM
}

(From the Department of Internal Medicine, Yale University School of Medicine, New Haven, Conn.)

(Submitted for publication June 21, 1950; accepted, August 28, 1950)

\section{INTRODUCTION}

In the Goulstonian lecture of $1936 \mathrm{McCance}$ (1) first clearly defined the physiological and chemical changes induced by the depletion of salt in normal man. He confirmed Gamble's (2) postulate of the jealously guarded constancy of the concentration of total base in the serum. This was largely effected by the elaboration of a urine virtually free of salt soon after the institution of salt deprivation. More recently Platt (3) noted that the concentration of total base may fall very slightly in a normal person just before maximal tubular reabsorption of salt occurs. This renal defense is lacking in Addison's disease and in those cases of kidney disease in which salt continues to be excreted in the urine at a time when the concentration of sodium in the serum has fallen below normal.

Subsequent to McCance's classical description, Winkler and Crankshaw (4) described a new syndrome characterized by renal salt-wasting and subnormal concentrations of sodium in the serum in patients with pulmonary disease. Of the three cases documented, two had far-advanced pulmonary tuberculosis and one had carcinoma of the lung. Besides excreting salt under conditions which would normally be associated with maximal reabsorption of sodium, these patients rapidly eliminated intravenously administered salt and were unable to maintain the concentration of sodium in the serum at a normal level. Adrenal

\footnotetext{
1 Aided by a grant from the Fluid Research Funds of the Yale University School of Medicine, and by an institutional grant from the National Heart Institute, U. S. Public Health Service.

2 Present address: College of Medicine, University of Vermont, Burlington, Vt.

3 Work done in part during the tenure of a Postdoctorate Fellowship, U. S. Public Health Service.

4 Work done in part while a fellow of the Dazian Foundation for Medical Research and during the tenure of a Life Insurance Medical Research Fellowship. Present address: National Heart Institute, Bethesda, Md.
}

cortical extract was without influence on the persistent wastage of salt in one patient.

Thorn, Howard and Dayman (5) analyzed a large number of cases with pulmonary tuberculosis and found none with a subnormal concentration of sodium in the serum. However, two of his patients did continue to excrete sodium after three days on an intake low in salt. They did not confirm Winkler's findings and attributed the low concentration of chloride in the serum in many of his patients to retention of bicarbonate.

- Westover, Stiven, and Garry (6) observed low concentrations of sodium in the serum of 55 of 114 patients with tuberculosis. In a small number in whom balances were calculated there was evidence suggestive of wastage of salt. More recently Kolmer and his associates (7) analyzed the chemical data of a group of tuberculous subjects statistically. The concentration of total base was somewhat lower than normal. It is of interest that this depression was better correlated with magnitude of daily temperature variations than with the severity of the disease as estimated by X-ray examinations.

Since none of these studies clearly defined the chemical anatomy or elucidated the mechanism of the syndrome of pulmonary salt-wasting, this study was undertaken. - It was hoped that by investigating the role of the kidneys, the adrenal cortices, as well as the status of the cellular structures of the body, an explanation for the chronic depression of the effective osmotic pressure of the extracellular water might be found. Also of importance to this study was the development of a means of differentiating this condition from Addison's disease since both are encountered in patients with tuberculosis.

\section{EXPERIMENTAL MATERIAL AND PROCEDURE}

Ten male patients with advanced tuberculous disease and hyponatremia were studied. Four of the ten were Negroes. One of the patients had miliary tuberculosis 


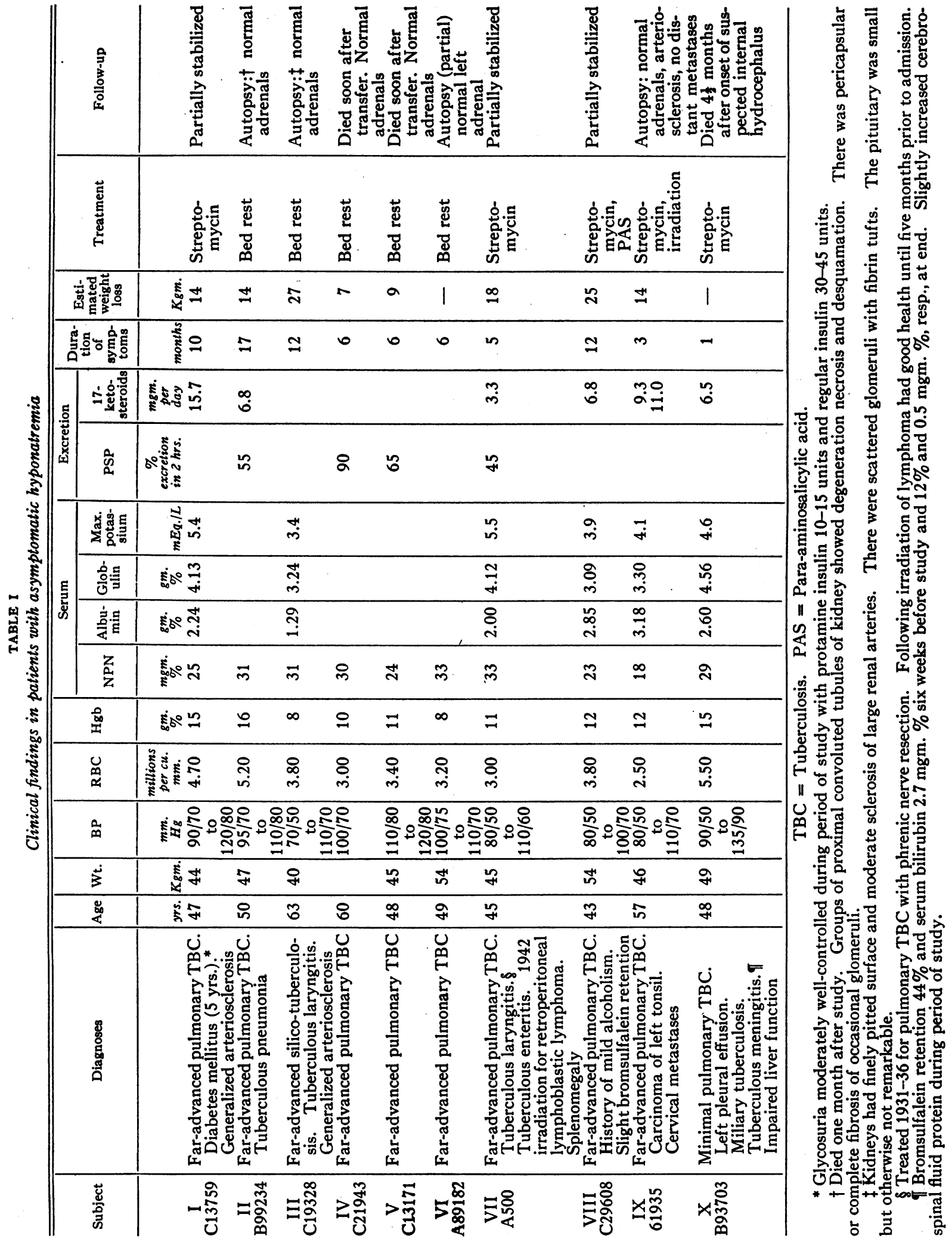


with pulmonary infiltration limited to one lobe. One Negro male with tuberculosis of the adrenals and Addison's disease was also investigated during a crisis. Normal concentrations of sodium in the serum were found in 14 other patients with moderate or advanced tuberculosis, in three with advanced bronchiectasis, and in five with various conditions associated with malnutrition. In addition, the hospital records of a large number of patients with abnormally low concentrations of sodium in the serum and continued excretion of sodium were searched for instances in which the hyponatremia was not definitely secondary to kidney disease, adrenal insufficiency, or over-hydration during therapy. Three such instances were found, but there was not sufficient evidence to include them definitely in the present group. The course, follow up, and subsidiary diagnoses of the ten tuberculous patients are indicated in Table I. Some or all of the following investigative procedures were carried out on each patient depending upon the clinical condition and severity of the illness.

Subjects studied over an extended period were provided with a basic diet adequate in calories and protein, but containing not over $0.5 \mathrm{gm}$. of sodium chloride per day. This was supplemented in some instances by milk and cream containing $0.3 \mathrm{gm}$. of salt. To this, weighed quantities of table salt were added daily. Consecutive 24-hour collections of urine were made during the entire period of study and were analyzed for chloride and sodium. Five of the patients were treated with 1-2 gm. of streptomycin and one with $10 \mathrm{gm}$. of para-aminosalicylic acid per day as well, but no essential change in their regime was made during the period of investigation.

Renal clearances of endogenous creatinine were meas- ured in seven patients. These patients were not catheterized, but a moderate diuresis was induced to minimize the error from residual urine. In one patient the clearances of mannitol and of urea were determined.

In five patients acute balances of sodium and of chloride were measured on one or more occasions over periods of 24 hours at the beginning of which an infusion containing $15 \mathrm{gm}$. of sodium chloride as a $3 \%$ solution was given. Additional salt was given by vein or per os in all but one patient.

Five or $20 \mathrm{mgm}$. of desoxycorticosterone acetate in oil 5 were administered to four patients in one or two intramuscular doses daily. Ten cc. of aqueous adrenal cortical extract (Wilson) or 1 cc. of Lipo-adrenal extract (Upjohn) were given in intramuscular doses at intervals of 12 hours.

Both procedures of the "water test" for adrenal insufficiency were carried out as described by Robinson, Power, and Kepler (8). The decrease in circulating eosinophiles following the infusion of $1.5 \mathrm{mgm}$. of epinephrine in normal saline given over a period of one hour was studied in three patients according to the technique of Recant, Forsham, and Thorn (9). In the remaining patients $0.3 \mathrm{mgm}$. of epinephrine was given subcutaneously as described by Thorn and his colleagues (10). Total eosinophile counts were made four hours after the epinephrine was given, and in the majority of patients at two hours as well. Urine for determination of 17 -ketosteroids was preserved with 1 cc. of concentrated hydrochloric acid per liter and refrigerated until analyzed.

\footnotetext{
${ }^{5}$ Kindly furnished by Dr. Kenneth Thompson of Organon, Inc., Orange, N. J.
}

TABLE II

Effect of variations in the intake of sodium chloride; analyses of serum and urine

\begin{tabular}{|c|c|c|c|c|c|c|c|c|c|c|c|c|c|c|}
\hline \multirow{3}{*}{ Subject } & \multicolumn{7}{|c|}{ Free intake of sodium chloride } & \multicolumn{3}{|c|}{$\begin{array}{l}\text { Maximum intake of } \\
\text { sodium chloride }\end{array}$} & \multicolumn{4}{|c|}{ Minimum intake of sodium chloride } \\
\hline & \multicolumn{3}{|c|}{ Serum } & \multicolumn{4}{|c|}{ Urinary excretion } & \multirow{2}{*}{ Intake } & \multirow{2}{*}{$\begin{array}{l}\text { Total } \\
\text { time }\end{array}$} & \multirow{2}{*}{$\begin{array}{c}\text { Final } \\
\text { serum } \\
\text { sodium }\end{array}$} & \multirow{2}{*}{$\begin{array}{c}\text { Average } \\
\text { intake }\end{array}$} & \multirow{2}{*}{$\begin{array}{l}\text { Total } \\
\text { time }\end{array}$} & \multirow{2}{*}{$\begin{array}{l}\text { Final } \\
\text { serum } \\
\text { sodium }\end{array}$} & \multirow{2}{*}{$\begin{array}{c}\text { Final } \\
\text { sodium } \\
\text { excretion }\end{array}$} \\
\hline & $\mathrm{Na}$ & $\mathrm{Cl}$ & $\mathrm{HCO}_{3}$ & Soc & dium & $\mathrm{Ch}$ & loride & & & & & & & \\
\hline
\end{tabular}

* One day previously

$\dagger$ Desoxycorticosterone acetate in oil $5 \mathrm{mgm}$. per day given over this period

† Two days previously

24.8 on admission seven days previously

If As chloride 
TABLE III

Alterations associated with administration of large amounts of $\mathrm{NaCl}$

\begin{tabular}{|c|c|c|c|c|c|c|c|c|}
\hline \multirow{2}{*}{ Subject } & \multirow{2}{*}{$\begin{array}{l}\text { Sodium } \\
\text { intake }\end{array}$} & \multirow{2}{*}{$\begin{array}{l}\text { Sodium } \\
\text { retained }\end{array}$} & \multicolumn{3}{|c|}{ Concentrations of $\mathrm{Na}$ in extracellular water } & \multirow{2}{*}{$\underset{\mathbf{W t} .}{\Delta}$} & \multirow{2}{*}{$\begin{array}{l}\stackrel{\Delta}{\text { Plasma }} \\
\text { volume }\end{array}$} & \multirow{2}{*}{$\underset{\mathbf{N a}}{\Delta}$} \\
\hline & & & Initial & Final & Anticipated* & & & \\
\hline $\begin{array}{c}\text { I-A } \\
\text { I-B } \\
\text { II } \\
\text { VI } \\
\text { VII } \\
\text { X }\end{array}$ & $\begin{array}{c}m E q . \\
427 \\
427 \\
256 \\
856 \\
427 \\
324\end{array}$ & $\begin{array}{l}\% \\
93 \\
20 \\
61 \\
98.5 \\
58 \\
41\end{array}$ & $\begin{array}{c}m E q . / L \\
133 \\
137 \\
128 \\
114 \\
129 \\
131\end{array}$ & $\begin{array}{c}m E q . / L \\
134 \\
137 \\
136 \\
135 \\
137 \\
136\end{array}$ & $\begin{array}{c}m E q . / L \\
145 \\
139 \\
133 \\
137 \\
136 \\
134\end{array}$ & $\begin{array}{r}\text { Kgm. } \\
1.5 \\
-0.4 \\
- \\
\overline{-} .2 \\
-0.3\end{array}$ & $\begin{array}{r}\% \\
18 \\
1 \\
7 \\
35 \\
8 \\
-\end{array}$ & $\begin{array}{l}m E q . \\
-87 \\
-42 \\
-\quad 92 \\
-132 \\
-\quad 22 \\
-45\end{array}$ \\
\hline EV† & 739 & 95.3 & 129 & 136 & 147 & - & 27 & +104 \\
\hline
\end{tabular}

* Estimated from positive balance of $\mathrm{Na}$ and assuming no change in total body water.

$\dagger$ Patient with adrenal cortical insufficiency in crisis.

The urinary excretion of sodium and chloride as influenced by the gradual reduction of dietary salt was measured.

\section{METHODS}

Serum protein fractions were determined by the Milne modification of the technique of Majoor (11), urea by the gasometric method of Van Slyke using urease or hypobromite (12), and mannitol by Elkinton's modification of the Smith, Finkelstein, and Smith procedure (13). Creatinine was determined by the method of Peters (14). Readings were made exactly 20 minutes after the addition of alkaline picrate, since filtrates from serum darken progressively on standing. 17-Ketosteroids in urine were estimated colorimetrically either by the method of Cahen and Salter (15) or of Holtorff and Koch (16). Eosinophiles were stained by the technique of Randolph (17), using phloxine $B$ in a $1: 1$ aqueous dilution of propylene glycol. The average of from two to four counts in a Levy chamber $0.2 \mathrm{~mm}$. in depth was taken. Other methods used in this laboratory have been re-

TABLE IV

Effect of variations of the concentration of sodium in the serum on renal clearances in patients with asymptomatic hyponatremia

\begin{tabular}{|c|c|c|c|c|c|}
\hline \multirow{2}{*}{ Subject } & \multirow{2}{*}{ wt. } & \multirow{2}{*}{$\begin{array}{c}\text { Serum } \\
\text { sodium }\end{array}$} & \multicolumn{3}{|c|}{ Renal clearance* } \\
\hline & & & $\begin{array}{l}\text { Endogenous } \\
\text { creatinine }\end{array}$ & Mannitol & Urea \\
\hline $\begin{array}{c}\text { IV } \\
\text { VI } \\
\text { VII } \\
\text { VIII } \\
\mathbf{X}\end{array}$ & $\begin{array}{c}\text { Kgm. } \\
44 \\
\\
\\
43 \\
54 \\
45 \\
54 \\
49\end{array}$ & $\begin{array}{c}m E q . / L \\
134 \\
126 \\
133 \\
127 \\
131 \\
112 \\
135 \\
126 \\
134 \\
128 \\
125\end{array}$ & $\begin{array}{l}61 \\
73 \\
67,69 \\
64,69 \\
62,62 \\
73,75 \\
80,73\end{array}$ & $\begin{array}{c}c c . / \min . \\
111,108 \\
101,102\end{array}$ & $\begin{array}{l}69,66 \\
82,76\end{array}$ \\
\hline
\end{tabular}

* Calculations for consecutive clearance periods are given. ported in previous publications (18). The methods for calculating changes in plasma volume from changes in relative red cell volume and hemoglobin and for changes in the distribution of water and electrolytes have been described elsewhere $(19,20)$.

\section{RESULTS}

The analytical and derived data are presented in Tables I-VI and Figures 1-4.

\section{General Clinical Observations}

All the members of this group of patients in whom hyponatremia was found were chronically ill and malnourished, and four (II, III, VI, and VII) were acutely ill when first studied. Seven of the patients died within one to five months following admission, and the remaining three have a poor prognosis for ultimate recovery. The essential clinical data on these patients are summarized

TABLE V

Robinson-Power-Kepler water tests in three patients with asymptomatic hyponatremia

\begin{tabular}{|c|c|c|c|c|c|}
\hline \multirow{3}{*}{ Subject } & \multirow{3}{*}{ Date } & \multirow{3}{*}{$\begin{array}{l}\text { Serum } \\
\text { sodium }\end{array}$} & \multirow{2}{*}{\multicolumn{2}{|c|}{$\begin{array}{c}\text { Procedure I } \\
\text { Urine volume }\end{array}$}} & Procedure II \\
\hline & & & & & \multirow[b]{2}{*}{$\begin{array}{l}\text { "A" } \\
\text { value }\end{array}$} \\
\hline & & & $\begin{array}{l}\text { Nig̀ht } \\
\text { period } \\
(9 \text { hrs.) }\end{array}$ & $\begin{array}{c}\text { Maximum } \\
\text { day } \\
\text { period } \\
(1 \mathrm{hr} .)\end{array}$ & \\
\hline$\underset{\mathbf{X}}{\text { VII }}$ & $\begin{array}{r}11-8-48 \\
11-27-48 \\
12-7-48 \\
3-17-49 \\
8-30-49\end{array}$ & $\begin{array}{c}m E q . / L \\
126.0 \\
127.0 \\
129.7 \\
135.0 \\
130.0\end{array}$ & $\begin{array}{l}c c . \\
400 \\
650 \\
330 \\
920 \\
615\end{array}$ & $\begin{array}{l}c c . \\
240 \\
205 \\
195 \\
355 \\
265\end{array}$ & $\begin{array}{l}40 \\
30 \\
39 \\
10^{*} \\
43\end{array}$ \\
\hline
\end{tabular}

* The intake of sodium chloride was $15.8 \mathrm{gm}$. for seven days prior to the test. 
TABLE VI

The effect of administration of epinephrine on circulating cosinophiles in six patients with asymptomatic hyponatremia

\begin{tabular}{|c|c|c|c|c|}
\hline \multirow{3}{*}{ Subject } & \multirow{3}{*}{$\begin{array}{c}\text { Epineph- } \\
\text { rine } \\
\text { admin. }\end{array}$} & \multicolumn{3}{|c|}{ Circulating eosinophiles } \\
\hline & & \multirow{2}{*}{$\begin{array}{l}\text { Initial } \\
\text { count }\end{array}$} & \multicolumn{2}{|c|}{$\%$ fall } \\
\hline & & & $2 \mathrm{hrs}$ & $4 \mathrm{hrs}$ \\
\hline 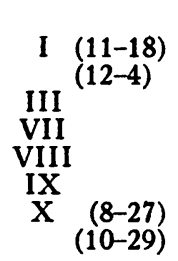 & $\begin{array}{c}m g m . \\
1.5 \\
1.5 \\
1.5 \\
0.3 \\
0.3 \\
0.3 \\
0.3\end{array}$ & $\begin{array}{c}\text { per cu. mm. } \\
300 \\
300 \\
<3 \\
116 \\
131 \\
920 \\
280 \\
153\end{array}$ & $\begin{array}{l}\% \\
56 \\
31 \\
70\end{array}$ & $\begin{array}{r}54 \\
57 \\
53 \\
2 \\
20\end{array}$ \\
\hline
\end{tabular}

in Table I. The findings over the entire period of study in two patients typical of the group are shown in Figures 1 and 2 . The reduced red blood cell counts and hemoglobin concentrations in the majority of the patients, together with the low concentrations of serum albumin, are consistent with the degree of malnutrition found. On the other hand, many other patients not reported in detail in the present study did not have hyponatremia, but had an apparently comparable degree of chronic illness and malnutrition. All the patients had some degree of hypotension which was at times marked. No correlation could be found, however, between the degree of hyponatremia and the level of the blood pressure. This is illustrated in the graph of the findings in two patients (Figures 1 and 2). Two patients (VII and VIII) had increased pigmentation over pressure points, and one (III) had slate-gray pigmentation of buccal membranes. The concentration of non-protein

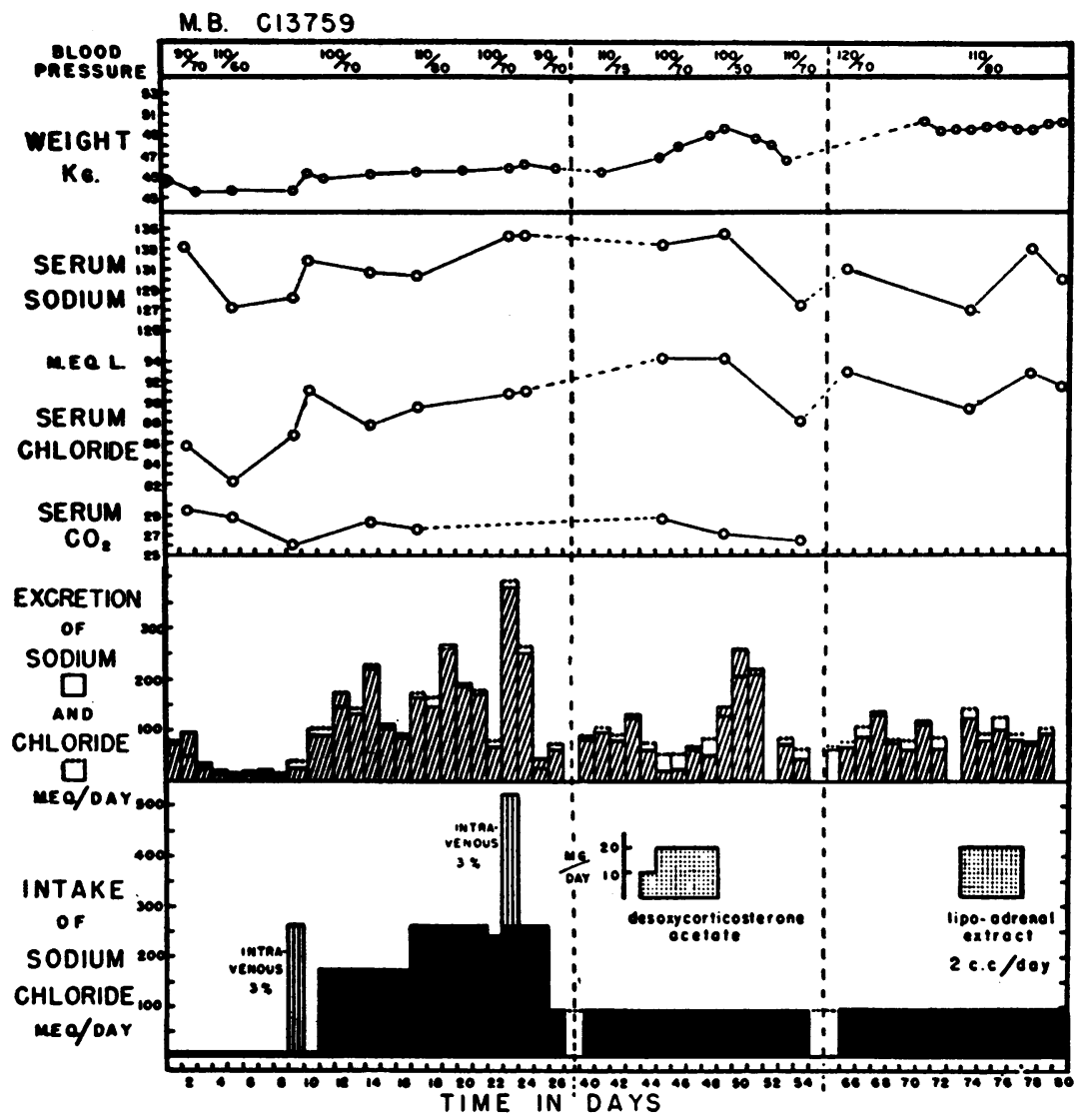

Fig. 1. Changes in Weight, Blood Pressure, Serum Concentrations of Electrolytes, and Urinary Excretion of Sodium and Chloride in Relation to Variations in Intake of Salt and to Administration of Desoxycorticosterone Acetate and of Adrenal Cortical Extract in a Patient (I) with ASYMPTOMATIC HYPONATREMIA 
nitrogen in the blood was normal in all patients and in none was there gross evidence of renal or cardiovascular disease, with the exception of one (I), who had calcification of the abdominal aorta by X-ray, and another who gave a history of hypertension of unknown degree nine years previously. Only one patient (III) was observed to have significant carbon dioxide retention, in spite of the severity of the pulmonary involvement in the majority of the other patients. Concentrations of potassium in the serum were within normal limits. When these patients were eating the ward diet with a free intake of salt, which was usually the case when they were first studied, they continued to excrete from 40 to $90 \mathrm{mEq}$. of sodium per day in spite of the fact that the concentrations of sodium in the serum ranged from 122 to 131 mEq./L (Table II).

In two patients the tendency toward hyponatremia was found to be reversible. It is shown in Figure 2 that when this patient (VII) was again given a diet low in sodium 75 days after the first period of deprivation, he maintained his concentration of sodium in the serum between 138 and $136 \mathrm{mEq} . / \mathrm{L}$. During the interval his weight had increased $2 \mathrm{Kgm}$. on a regime of bed rest and streptomycin, his sputum production had decreased by a third, and his daily temperature rises had decreased from an average of 102 to 100 degrees F. However, the X-ray of his chest was unchanged. Nine months after his first period of deprivation of salt, a second patient (I) was placed on a diet for seven days which was as low in sodium as could be arranged at the sanitorium to which he had been sent. Over this period his concentration of sodium in the serum remained constant at 133 to $134 \mathrm{mEq} . / \mathrm{L}$. During this interval a pneumoperitoneum had been induced and he had gained considerable weight.

\section{The effects of variation in salt intake}

Five patients (I, III, VII, VIII, and IX) were given a moderate or high intake of salt for a period of five to 12 days. In one who suffered from

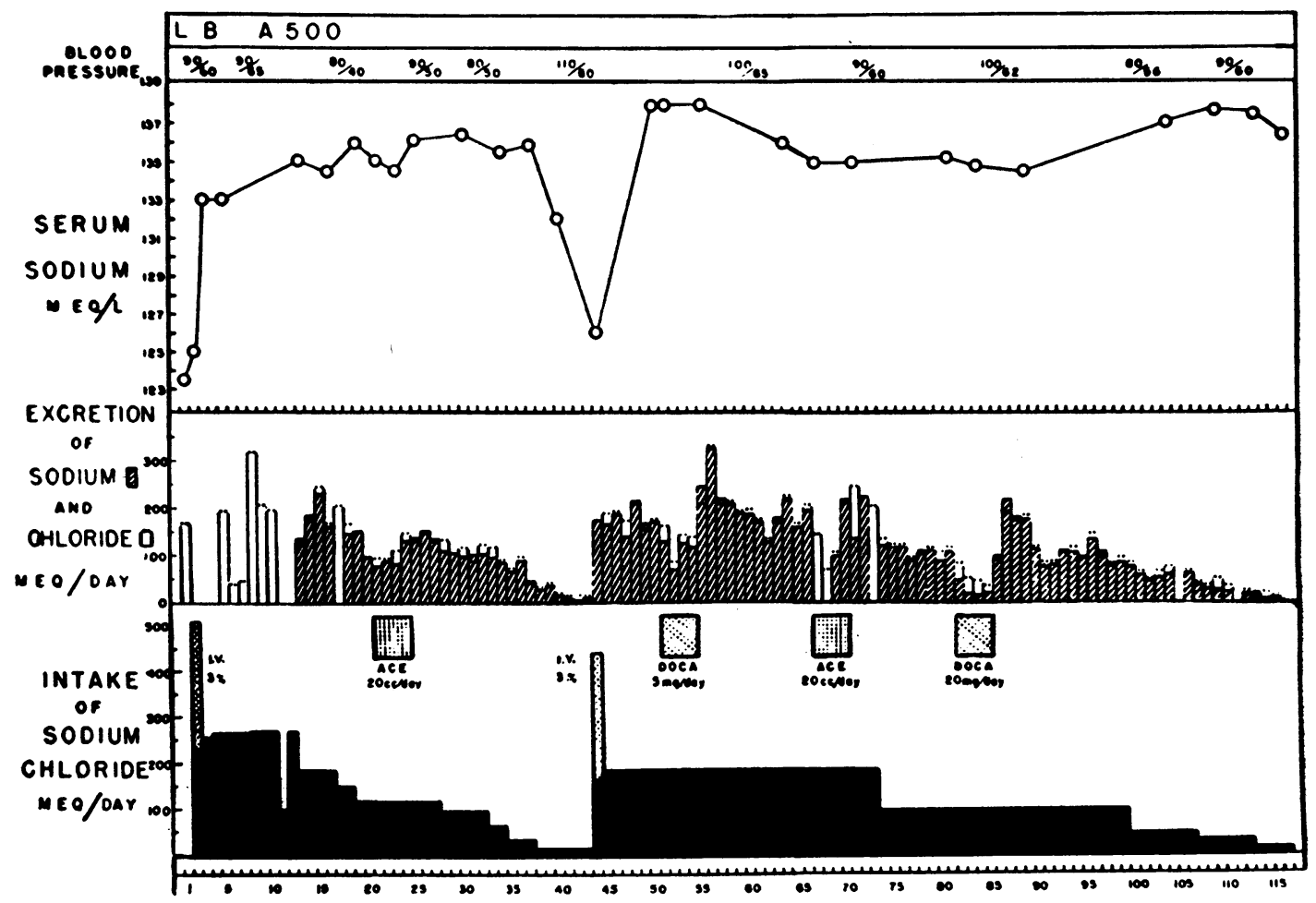

Fig. 2. Changes in Blood Pressure, Serum Concentrations of Sodium, and Urinary Excretion of Sodium and Chloride in Relation to Variations in Intake of Salt and to Administration of Desoxycorticosterone Acetate and of Adrenal Cortical Extract in a Patient (VII) with Asymptomatic HYPON ATREMIA 


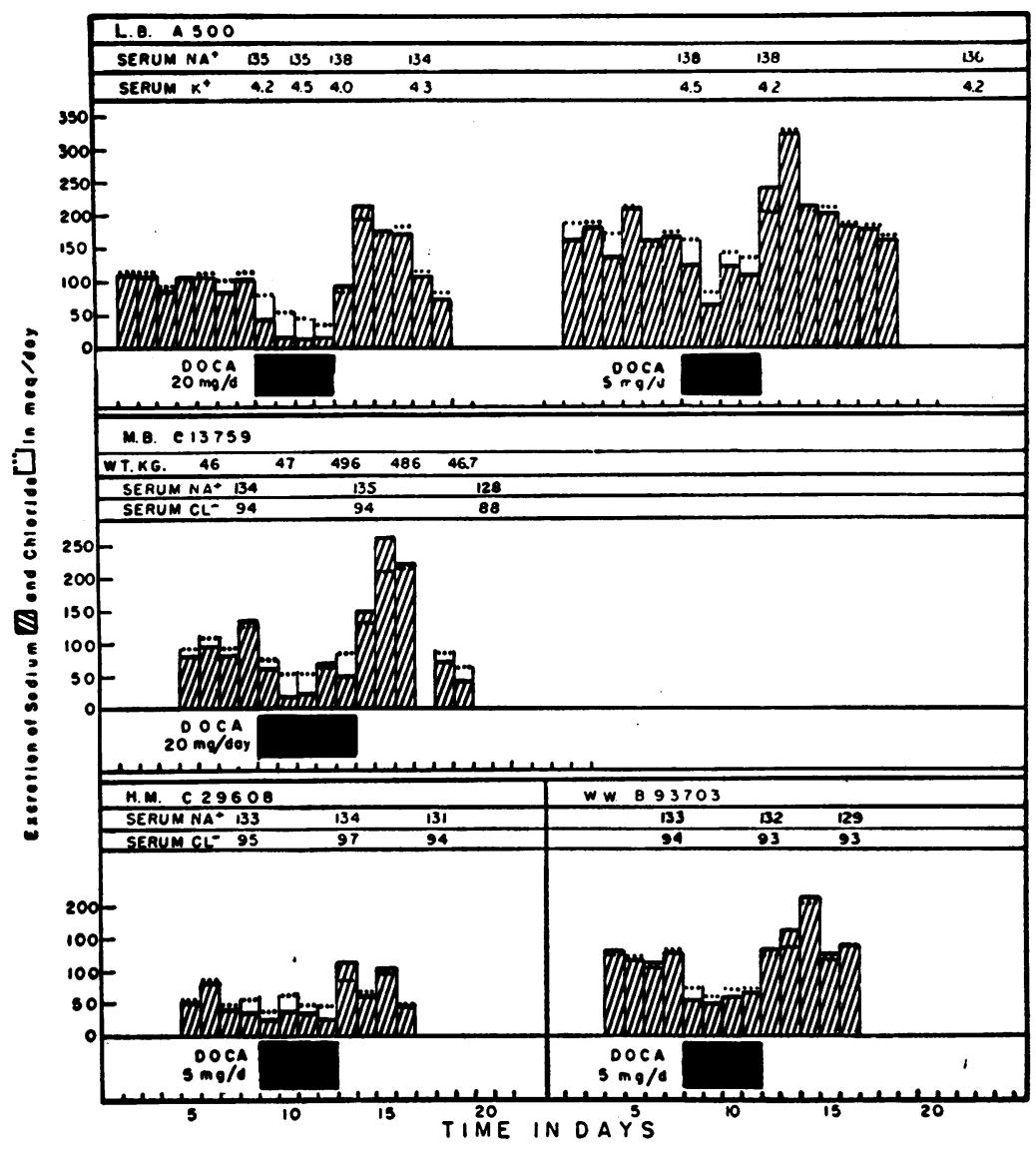

Fig. 3. Effect of Desoxycorticosterone Acetate upon the URinary Excretion of Sodium and Chloride in Four Patients with Asymptomatic HYPONATREMIA

advanced tuberculosis and carcinoma of the pharynx treated with irradiation, daily infusions containing $13.5 \mathrm{gm}$. of sodium chloride over a fiveday period failed to raise the concentration of sodium in the serum above $125 \mathrm{mEq}$./L. There was no evidence of congestive failure and no peripheral edema in this case. Three of the patients given more than $185 \mathrm{mM}$. of salt per day had final concentrations of sodium in the serum in the low normal range, $132-135 \mathrm{mEq}$./L. In two other patients (II and X) final concentrations of sodium in the serum of $133-135 \mathrm{mEq} . / \mathrm{L}$ were observed following a somewhat lower intake of salt.

The sodium in the diet of five patients (I, VI, VII, VIII, and IX) was reduced to 8-13 mEq./ day for two days or more. Since the quantity of salt added to the basic diet had been variously restricted during the preceding periods, this did not constitute an abrupt deprivation of salt. In all but one instance the renal excretion of sodium was reduced to $8 \mathrm{mEq}$./day or less, and in all instances the concentration of sodium in the serum fell before the minimal urinary excretion of this ion was reached. This is illustrated in Figure 1, days 2-8 and Figure 2, days 40-42. A fifth subject (II) who was acutely ill with tuberculous pneumonia had an excretion of $29 \mathrm{mEq}$./day of sodium and a concentration in the serum of $125 \mathrm{mEq}$./L when the intake of salt was reduced to $43 \mathrm{mEq}$./day. However, during these studies of deprivation the excretion of sodium, while often sharply reduced, did not reach the extremely low values usually associated with hyponatremia due to depletion of salt in other conditions. It was striking to observe throughout the studies that these patients were free of symptoms attributable to depletion of salt and sometimes had an indifference to their dietary salt 


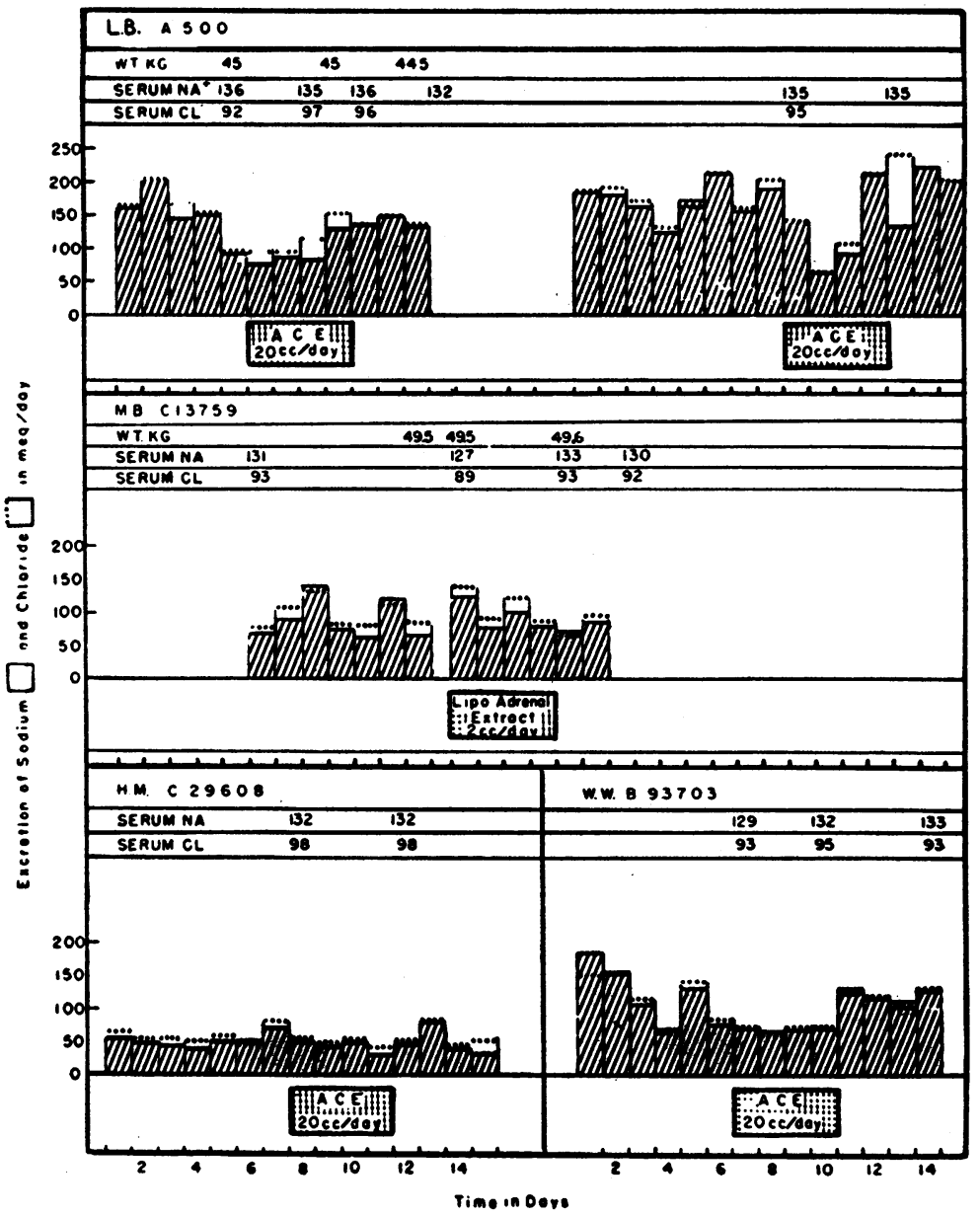

Fig. 4. Effect of Adrenal Cortical Extract upon the Urinary Excretion of Sodium and Chloride in Four Patients with Asymptomatic HYPONATREMIA

when the concentrations of sodium in the serum were at levels generally associated with collapse in other situations involving depletion of salt. Only one patient $(\mathrm{X})$ exhibited craving for salt when on a sodium restricted regime. Muscle cramps were not seen.

One patient (VI) demonstrated that this group is not immune to the effects of true depletion of salt. This patient was acutely ill, febrile, and sweating considerably. It was later learned that he had rejected a considerable portion of the 85 $\mathrm{mEq}$. of sodium that were added to his diet for a three-day period. He excreted only $12 \mathrm{mEq}$. of sodium the first day that his intake of this ion was reduced to $13 \mathrm{mEq}$. During the following day a bout of mild diarrhea added to the loss of sodium in sweat and sputum, and the concentration of sodium in his serum fell from 118 to $112 \mathrm{mEq} . / \mathrm{L}$. At this point he developed diaphoresis, acute anxiety, and borderline vascular collapse, all of which were rapidly improved by an infusion of hypertonic saline. It is notable that these signs and symptoms developed when the concentration of sodium in the serum was only $6 \mathrm{mEq}$. below that at which the renal excretion of sodium had been sharply reduced. In contrast to the crisis in Addison's disease, the non-protein nitrogen concentration of the blood did not rise above $33 \mathrm{mgm}$. \%, nor the potassium above $5.1 \mathrm{mEq} . / \mathrm{L}$. There was no elevation of temperature.

When there were alterations in the quantity of salt ingested as described above, there were variations in the concentrations of sodium in the serum of 2. to $12 . \mathrm{mEq}$./L. An additional patient 
(X) whose intake of salt was not pushed to a high level had a variation of only $3.5 \mathrm{mEq} . / \mathrm{L}$ in his concentration of sodium in the serum. The minimum concentrations of sodium in Table II occurred before or approximately at the time when the excretion of sodium had first reached a low level, so they reflect a loss of sodium via the urine.

Infusions of $256 \mathrm{mM}$. of sodium chloride as a $3 \%$ solution were administered to five patients. In addition, all but one received additional salt in the course of a 24-hour period either as normal saline intravenously or as table salt by mouth (Table III). For comparison, data are also presented from a patient with Addison's disease (EV) in crisis during the first 18 hours of therapy. All the patients except VI and EV had free access to water during the balance period. When the initial concentration of sodium was low, from $41 \%$ to $98.5 \%$ of the administered salt was retained (although in this calculation no correction was made for the variable loss of sodium in sweat). There were no significant shifts of sodium between the intracellular and extracellular compartments.

It is assumed that where an antecedent depletion of both water and sodium exist, water will be retained following the administration of salt and will be manifest by increases in body weight and plasma volume. In addition, the observed concentration of sodium in the extracellular water at the end of the balance period should be less than the concentration of sodium as estimated from the positive balance of this ion with the assumption that there had been no increase in total body water. This "anticipated" concentration of sodium in the extracellular water is presented in Table III.

The insignificant changes in weight and in the per cent increase in plasma volume and the good agreement between the observed and anticipated concentrations of sodium in the extracellular fluid suggest that in patients I-B, II, VII, and X the volume of water was not previously contracted. In contrast, in patients I-A and VI, who had suffered antecedent extrarenal losses of salt and water, there were retentions of salt and increases in plasma volume similar to those of the patient (EV) with Addison's disease. Moreover, there was considerable disagreement between the observed and anticipated concentrations of sodium in the extracellular water in patients I-A and EV.
The agreement of this function in patient VI may be explained in part by a marked diaphoresis that occurred early in the balance period.

Endogenous creatinine clearances ranged from 61 to $80 \mathrm{cc} . / \mathrm{min}$. (Table IV). Figures for the heights of these patients are not available, but in view of their low weights, averaging $49 \mathrm{Kgm}$., it is probable that corrected clearances would fall within the low normal range. In two of the patients (VII and VIII) creatinine clearances were measured when the concentration of sodium in the serum had been forced to a maximum by a high intake of salt and again when the subject had been deprived of salt. Under these varying conditions the creatinine clearance either did not change (VII) (Figure 2, days 13 and 43) or was actually higher in the hyponatremic state (VIII). In an additional patient (I) mannitol clearances were similarly measured both when the concentration of sodium in the serum was low and when it was normal. These did not differ significantly. Urea clearances were somewhat higher at the lower concentration of sodium in the serum in this same patient.

\section{The response to adrenal steroids}

In two patients ( $I$ and VII) $20 \mathrm{mgm}$. of desoxycorticosterone acetate (DOCA) in oil administered for four days produced a sharp reduction in sodium excretion, followed by an increased excretion on discontinuing the injections (Figure 3). In patient I a gain in weight of 2.6 $\mathrm{Kgm}$. and the development of pitting edema of the extremities was noted during the period when DOCA was administered, while patient VII gained $2.1 \mathrm{Kgm}$. over the same period. Although an exact balance cannot be computed from the data available, both patients appeared to retain more water than could be accounted for on the basis of the quantity of sodium retained. Five mgm. of DOCA per day produced a similar but less marked reduction in the excretion of sodium in patients $\mathrm{I}, \mathrm{VII}$, and $\mathrm{X}$ which was also followed by a secondary increase in excretion above the basal level after cessation of the injections. The effect of injections at 12-hour intervals of $10 \mathrm{cc}$. of adrenal cortical extract (Wilson) or of an equivalent amount of lipo-adrenal extract (Upjohn) was studied in four patients. The results are shown in Figure 4. There was clearly no effect 
when lipo-adrenal extract was given to patient I or when aqueous extract was given to patient VIII. A reduction in the excretion of sodium occurred during a portion of the period in which aqueous extract was administered to patient VII on two occasions. However, the reduction preceded the injection on the first occasion and was not sustained during the entire period of administration on either occasion. In the case of patient $\mathrm{X}$ the excretion of sodium varied spontaneously during a number of weeks both before and after adrenal extract was given and reached a low value one and three days prior to the injections. There was no secondary increase in the excretion of sodium above the basal level on discontinuing the injections in any of the patients.

\section{Estimate of adrenal cortical function}

At one time or another during their course in the hospital a diagnosis of adrenal insufficiency was seriously entertained in four of the patients (I, III, VII, and X) on the basis of clinical or laboratory findings. It was of interest, therefore, to study their response to the current tests of adrenocortical function. The response to deprivation of salt has been described above.

In three of the patients (I, VII, and X) the Robinson-Power-Kepler water test was done. The results are given in Table V. Procedure I of the test was invariably positive in that the normal diuretic response to ingested water was not obtained. In only one patient (VII) was Procedure II positive, with an "A" value of 10 . This test, however, was done when the patient had taken $15.5 \mathrm{gm}$. of salt in his diet the preceding day, which is in excess of the "usual diet without salt" specified by the authors of the test. In one patient (I) the "A" value was not significantly changed when the test was repeated after he had been given $23 \mathrm{gm}$. of sodium chloride two days prior to the test.

The eosinopenic effect of epinephrine was studied in six patients. In all of these a decrease in circulating eosinophiles of $50 \%$ or greater was found on at least one test. The depression of eosinophiles was, however, apparently not as susstained as in normal subjects given these quantities of epinephrine, for when counts were made at two hours as well as at four hours, in four out of five instances the two-hour count was lower. Thus, patient $\mathrm{X}$ had no eosinopenic response at four hours in the initial test; a second test demonstrated a $70 \%$ fall in eosinophiles at two hours. The initial eosinophile count in one acutely ill patient (III) was less than 3 per cu.mm., so that epinephrine was not given.

The excretion of 17 -ketosteroids per 24 hours was low, $3.3 \mathrm{mgm}$., in one patient (VII) on a day shortly after his admission with fever and advanced tuberculosis. Five other patients had lownormal or normal values, the actual excretion appearing to be correlated with the state of nutrition of the patient.

A five-hour intravenous glucose tolerance test was normal in three patients tested (VII, VIII, and $\mathrm{X}$ ).

Six patients came to autopsy (II, III, IV, V, IX, and partial in VI) and all were found to have normal adrenals. Two patients (II and III) had renal lesions as described in Table II.

\section{DISCUSSION}

The ability to excrete an almost sodium-free urine, to retain a large amount of intravenously administered sodium without benefit of exogenous salt-retaining hormone, to respond with an eosinopenia to epinephrine, and the absence of gross or histologic evidence of adrenal cortical disease at post-mortem all militate against adrenal cortical hypofunction as the primary defect responsible for this clinical picture, although this cannot be completely excluded. Nor does this syndrome appear to be a primary abnormality of the kidneys. Examination of the urine in these patients usually revealed no abnormalities, and there were no evidences of renal insufficiency. The renal tubular cells responded by increasing the reabsorption of sodium when DOCA was administered in doses of 20 and $5 \mathrm{mgm}$. per day.

This abnormality seems not to be a specific derivative of tuberculosis since it has been reported in one case of non-tuberculous pulmonary disease (4). Moreover, although the observations are not completely convincing at this time, there are suggestions that it may be found among patients with non-pulmonary disease. The common denominator may not be an organ specific disorder, but a secondary effect in some instances 
of severe disease associated with debility and malnutrition. There are reports in the literature that lend some support to such a suggestion. Sunderman and Rose (21) studied a patient with an inadequate dietary intake who had a subnormal concentration of total base in the serum. Gollan (22) reported that the average concentration of sodium in the sera of marasmic Italian children was lower than normal. This must be interpreted with some caution, as these infants had a history of diarrheal disease.

The fact that this syndrome has none of the symptoms of true sodium depletion is most important. In the development of the usual types of salt depletion there is a negative water balance with a consequent contraction of the volume of body water as well as a reduction in its tonicity. It is probable that the contraction of the plasma volume which shares in the decrease of the extracellular water and the dilution of the cellular contents as a result of the hypotonicity of the extracellular water both contribute to the physiologic abnormalities noted in salt depletion. These abnormalities are characterized by a persistent hypotension, asthenia, disordered renal hemodynamics (as manifested by a depressed rate of glomerular filtration and urea clearance) and by nitrogen retention; and, finally, peripheral vascular collapse. The data from the present investigations do not suggest such a state. Although endogenous creatinine clearances may have been somewhat reduced, they were no lower when the concentration of the sodium in the serum was depressed. There was no nitrogen retention, and peripheral vascular collapse developed only when there had been extrarenal loss of salt and water leading to the development of true salt depletion. These patients do not appear to be suffering from a contraction of the volume of the extracellular fluid and plasma.

A hypothesis is offered to explain the mechanism of this syndrome which is admittedly speculative and unproven. It is that the primary defect in this abnormality is a chronic reduction of cellular osmolarity. The overall effects of this alteration would be an abnormal excretion of sodium in an effort to reduce the tonicity of the extracellular fluids in conformity with the primarily reduced tonicity of the intracellular fluids, but with the maintenance of normal volumes of body water. Although there is as yet no primary and independent evidence that such a state of chronically altered cellular osmolarity does occur, acute alterations in cellular osmolarity have been observed. This phenomenon has been suggested by several groups to explain certain results in their investigations (23-27).

The sequence of events that might follow such a primary decrease in cellular tonicity is as follows : the first event is a movement of water from the cells to the extracellular space in the interests of osmotic uniformity. At this point all the body fluids are relatively hypertonic and the intracellular volume is contracted. The hypertonicity and cellular dehydration provoke thirst and stimulate an increased secretion of the posterior pituitary antidiuretic hormone. More water is ingested and there is an increase in the reabsorption of water in the distal renal tubule. This tends to expand the body fluids, but reduces the tonicity of these fluids toward the "new" normal level. The cellular dehydration, the hypertonicity of the body fluids and the expanded extracellular volume may all be stimuli for the decreased reabsorption of sodium in the renal tubules, thus increasing the excretion of this ion. As sodium is excreted, water follows until the "new" level of tonicity and original volumes of the body fluids are achieved.

This mechanism provides for the maintenance of the volume of extracellular fluid and plasma, and, hence, avoids the undesirable effects of the usual type of salt depletion. With this mechanism in mind, it is clear why the calculation of the anticipated rise in concentration of sodium in the extracellular water agrees so closely with the observed when there is a net positive balance of sodium and the calculation is made with the premise that there is no change in total body water.

Although this hypothesis seems plausible and is not at variance with the observed data, it is admittedly unproven and awaits a critical test.

The differentiation of this syndrome from Addison's disease is an important clinical problem. The two procedures that seem to offer the most help in this regard are the demonstration of an eosinopenia following administration of epinephrine and the excretion of an almost sodium-free urine on a regime of minimal salt intake. The 
latter procedure is hazardous, but the risk can be minimized by careful and frequent clinical and chemical observations.

\section{SUMMARY AND CONCLUSIONS}

Ten patients with hyponatremia and pulmonary tuberculosis were studied. Nine had far-advanced pulmonary tuberculosis and one miliary tuberculosis with minimal pulmonary involvement. No frank evidence of renal or adrenal insufficiency was found. All showed advanced malnutrition, hypotension, and hypoalbuminemia. Abnormal retention of carbon dioxide was found in only one patient. When given free access to salt, they were found to excrete $40-90 \mathrm{mEq}$. of sodium per day in spite of concentrations in the serum ranging from 122 to $131 \mathrm{mEq}$./L. Five patients excreted as little as $5-29 \mathrm{mEq}$. of sodium per day when the dietary salt was severely restricted. The excretion of sodium, however, did not reach the low values usually associated with hyponatremia due to depletion of salt in other conditions. These patients did not present the clinical signs or symptoms or other evidence of sodium depletion. There was no evident dehydration, peripheral circulatory failure, or hyperkalemia. Renal clearances of creatinine, mannitol, or urea were essentially normal and were not lower when measured in the hyponatremic as opposed to the normal state. Five patients retained $41 \%$ to $98 \%$ of a large amount of salt given in a 24-hour period. Calculations from data obtained during acute balance periods following these infusions supported the hypothesis that these patients did not have a contracted body water. The concentration of sodium in the serum remained in the subnormal or low normal range despite high daily intakes of salt. This syndrome was reversed in two patients associated with clinical improvement. There was more lability in the concentration of sodium in the serum with varying intakes of salt than is usually observed in normal subjects. The concentrations varied during relatively short periods over a range of 2 to $12 \mathrm{mEq}$./L.

In three patients procedure I of the RobinsonKepler-Power water test was positive. In only one was the second part also positive. Six patients had an essentially normal eosinopenic response to epinephrine.
Four patients retained increased quantities of sodium when given desoxycorticosterone. There was no definite response to small doses of adrenal cortical extract. The adrenal glands were normal in the six patients who came to autopsy.

It is suggested that a primary reduction in cellular osmolarity may be the initiating factor in the development of this syndrome. The increased excretion of sodium at subnormal concentrations of this ion in the serum might represent an attempt to reduce extracellular tonicity to conform with a reduced cellular osmolarity.

An eosinopenic response to epinephrine and the ability to reduce the excretion of sodium on a regime free of salt aids in differentiating this syndrome from Addison's disease.

\section{ACKNOWLEDGMENTS}

We are grateful to Miss Alice Cattanach and the staff of the Diet Department for making possible the diets low in salt used in this study and to Miss Patricia Robinson, R.N., for her invaluable cooperation. The authors are indebted to Dr. John P. Peters for his guidance and criticism throughout the course of this study.

\section{BIBLIOGRAPHY}

1. McCance, R. A., Medical problems in mineral metabolism. Lancet, 1936, 1 ; 643, 704, 765, and 823.

2. Gamble, J. L., Ross, S. G., and Tisdall, F. F., The metabolism of fixed base during fasting. J. Biol. Chem., 1923, 57, 633.

3. Black, D. A. K., The renal excretion of water and salt. Irish J. M. Sc., 1949, 715.

4. Winkler, A. W., and Crankshaw, O. F., Chloride depletion in conditions other than Addison's disease. J. Clin. Invest., 1938, 17, 1.

5. Thorn, G. W., Howard, R. P., and Dayman, H., Electrolyte changes in pulmonary tuberculosis, with special reference to adrenal cortical function. Bull. Johns Hopkins Hosp., 1940, 67, 345.

6. Westwater, J. O., Stiven, D., and Garry, R. C., A note on the serum sodium level in patients suffering from tuberculosis. Clin. Sci., 1939, 4, 73.

7. Kolmer, H. S., Ellis, D., Smith, T., Collins, P., and Greisheimer, E. M., Acid-base condition in tuberculosis. Am. Rev. Tuberc., 1948, 57, 400.

8. Robinson, F. J., Power, M. H., and Kepler, E. J., Two new procedures to assist in the recognition and exclusion of Addison's disease; preliminary report. Proc. Staff Meet., Mayo Clinic, 1941, 16, 577.

9. Recant, L., Forsham, P. H., and Thorn, G. W., The effect of epinephrine on circulating eosinophils. Federation Proc., 1948, 7, 99. 
10. Thorn, G. W., Bayles, T. B., Massell, B. F., Forsham, P. H., Hill, S. R., Jr., Smith, S., III, and Warren, J. E., Studies on the relation of pituitary-adrenal function to rheumatic disease. New England J. Med., 1949, 241, 529.

11. Milne, J., Serum protein fractionation : a comparison of sodium sulfate precipitation and electrophoresis. J. Biol. Chem., 1947, 169, 595.

12. Peters, J. P., and Van Slyke, D. D., Quantitative Clinical Chemistry. Vol. II. Methods. Williams \& Wilkins, Baltimore, 1932.

13. Elkinton, J. R., The volume of distribution of mannitol as a measure of the volume of extracellular fluid, with a study of the mannitol method. J. Clin. Invest., 1947, 26, 1088.

14. Peters, J. H., The determination of creatinine and creatine in blood and urine with the photoelectric colorimeter. J. Biol. Chem., 1942, 146, 179.

15. Cahen, R. L., and Salter, W. T., Urinary 17-ketosteroids in metabolism; standardized chemical estimation. J. Biol. Chem., 1944, 152, 489.

16. Holtorff, A. F., and Koch, F. C., The colorimetric estimation of 17-ketosteroids and their application to urine extracts. J. Biol. Chem., 1940, 135, 377.

17. Randolph, T. G., Blood studies in allergy. I. The direct counting chamber determination of eosinophils by propylene glycol aqueous stains. J. Allergy, 1944, 15, 89.

18. Needham, J. W., The metabolism of potassium in diabetic acidosis. Yale J. Biol. \& Med., 1949, 22, 39 .
19. Elkinton, J. R., Danowski, T. S., and Winkler, A. W., Hemodynamic changes in salt depletion and in dehydration. J. Clin. Invest., 1946, 25, 120.

20. Elkinton, J. R., and Winkler, A. W., Transfers of intracellular potassium in experimental dehydration. J. Clin. Invest., 1944, 23, 93.

21. Sunderman, F. W., and Rose, E., Studies in serum electrolytes. XVI. Changes in the serum and body fluids in anorexia nervosa. J. Clin. Endocrinol., 1948, 8, 209.

22. Gollan, F., Blood and extracellular fluid studies in chronic malnutrition in infancy. $\mathrm{J}$. Clin. Invest., 1948, 27, 352.

23. Yannet, H., and Darrow, D. C., The effects of depletion of extracellular electrolytes on the chemical composition of skeletal muscle, liver, and cardiac muscle. J. Biol. Chem., 1940, 134, 721.

24. Elkinton, J. R., Winkler, A. W., and Danowski, T. S., Inactive cell base and the measurement of changes in cell water. Yale J. Biol. \& Med., 1944, 17, 383.

25. Seldin, D. W., and Tarail, R., Effect of hypertonic solutions on metabolism and excretion of electrolytes. Am. J. Physiol., 1949, 159, 160.

26. Gaudino, M., and Levitt, M. F., Influence of the adrenal cortex on body water distribution and renal function. J. Clin. Invest., 1949, 28, 1487.

27. Welt, L. G., Orloff, J., Kydd, D. M., and Oltman, J. E., An example of cellular hyperosmolarity. J. Clin. Invest., 1950, 29, 935. 